Retraction

\title{
Retraction: Middleton, B. and Cosgrove, S.M. Isolation and Elimination of Latent and Productive Herpes Simplex Virus from the Sacral and Trigeminal Ganglions. Proceedings 2020, 50, 92
}

Proceedings Editorial Office

MDPI, St. Alban-Anlage 66, 4052 Basel, Switzerland; proceedings@mdpi.com

Published: 13 January 2021

The journal retracts the Abstract [1] cited above. Following publication, concerns were brought to the attention of the publisher regarding misrepresentation of the affiliation of the first author. The author of the Abstract was listed as affiliated with the Department of Virology, ACU, North Sydney, Australia. The Australian Catholic University (ACU) in North Sydney confirmed that ACU does not have a Department of Virology and that the author has never been employed at the university [2].

The Abstract is therefore retracted.

\section{References}

1. Middleton, B.; Cosgrove, S.M. Isolation and Elimination of Latent and Productive Herpes Simplex Virus from the Sacral and Trigeminal Ganglions. Proceedings 2020, 50, 92.

2. ACU Not Connected to False Research Claims. Available online: https://www.acu.edu.au/aboutacu/news/2020/september/acu-not-connected-to-false-research-claims?utm_source=miragenews\&utm_ medium=miragenews\&utm_campaign=news (accessed on 20 October 2020).

Publisher's Note: MDPI stays neutral with regard to jurisdictional claims in published maps and institutional affiliations.

(C) 2021 by the authors. Licensee MDPI, Basel, Switzerland. This article is an open access article distributed under the terms and conditions of the Creative Commons Attribution (CC BY) license (http://creativecommons.org/licenses/by/4.0/). 